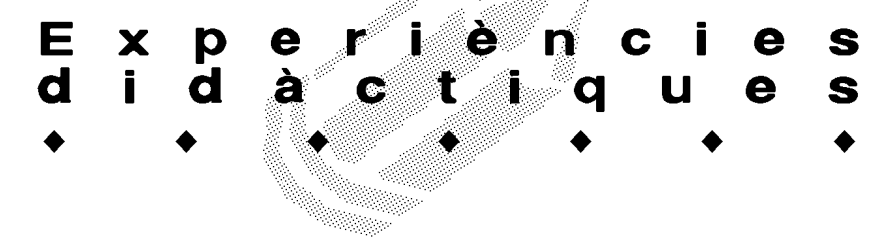

\title{
L'ARGUMENTACIÓ EN ALUMNES UNIVERSITARIS DE MAGISTERI DE LA UNIVERSITAT ROVIRA I VIRGILI. PRIMERA APORTACIÓ
}

\author{
Antoni Gavaldà Torrents (coord.) i Antoni Santisteban Fernández, Àrea de Didàctica de les Ciències \\ Socials. URV. \\ Carmen Conde Delgado de Molina, Àrea de Psicologia Evolutiva i de l'Educació. URV. \\ Luisa Girondo Pérez, Àrea de Didàctica de les Matemàtiques. URV. \\ Albert Macaya Ruiz, Àrea de Didàctica de I'Expressió Plàstica. URV. \\ Isabel Viscarro Tomàs, Àrea de Didàctica de I'Expressió Corporal. URV.
}

\section{Bases conceptuals}

El grup de recerca de la URV "Investigació didàctica i continguts curriculars", des del curs 1999-2000, ha anat desenvolupant una activitat de recerca relacionada amb les capacitats cognitivo-lingüístiques implicades en la construcció dels coneixements dins el marc de les àrees curriculars a què pertanyen els autors d'aquest treball. En línia amb la nostra tasca professional com a formadors de mestres, hem centrat l'estudi en els alumnes de formació inicial del professorat d'educació Infantil i Primària, en totes les seves especialitats. El treball que presentem s'emmarca en la tendència que, en els darrers anys, contempla l'ensenyament com un procés d'ensenyar a pensar més que no pas com una transmissió unidireccional de continguts.

El supòsit de partida l'hem formulat en aquests termes: un millor coneixement de com els nostres alumnes raonen, fonamenten i sustenten la seva visió del món en tot allò que afecta les àrees implicades en l'educació obligatòria i que hauria d'aportar moltes pistes de com millorar la formació, sobre una base crítica i reflexiva. El punt d'arrencada aniria en la línia, tal com ens recorden Gómez i Prat (1998), que professorat i alumnat creen i desenvolupen a l'aula, en el dia a dia, formes comunes de conceptualitzar els materials, els continguts $i$, en general, tots els elements del procés educatiu. Conseqüentment, els significats són "negociats" a l'aula, són producte d'una interacció. Seguint amb aquest plantejament, una construcció crítica del coneixement no és possible sense una major consciència de com aquesta interacció es produeix. Seguint la màxima de crear professionals reflexius $\mathrm{i}$ crítics, capaços d'analitzar sobre la seva pràctica, creiem que cal encoratjar els alumnes a revisar el seu pensament en dos sentits: escatint les fonts de les seves idees i creences $i$, alhora, tenint present aquesta dimensió dialèctica de l'educació basada en la creació d'espais de significació compartida.

Una primera línia de treball, en aquest sentit, va ser l'estudi de l'opinió i el judici valoratiu en els alumnes de l'Ensenyament de Mestres sobre l'emissió d'opinions i les seves fonts. Les aportacions del grup van ser àmpliament exposades en diversos fòrums de debat (AA:DD, 2000) o centrades en una àrea concreta (CONDE, GAVALDÀ, SANTISTEBAN, 2000a i 2000b), (VISCARRO, CONDE, CAMPS, 2000) (MACAYA, CONDE, 2001). Gairebé com una continuació natural d'aquest primer estadi situacional, el centre d'interès va desplaçar-se cap a l'argumentació. Com a grup ens vam adonar que l'argumentació era una de les pedres angulars en la concepció dialèctica de l'educació de què hem parlat. Si els professionals de l'educació hem de saber crear àrees de consens en comptes d'imposar reiteradament en format cíclic sabers immutables $\mathrm{i}$ preestablerts, cal dotar els futurs ensenyants d'eines de reflexió que siguin capaces de demostrar, de convèncer, de raonar, és a dir, de crear coneixement a partir d'estratègies reflexives i crítiques, posant en joc el diàleg i la confrontació d'opinions. Fidels a aquesta darrera premissa, argumentar implicaria un seguit d'accions i estratègies tals com produir raons, examinar la seva rellevància i pertinença, vincular-les amb normes de caràcter universal, preveure les excepcions, trobar possibles deduccions, etc., sobre la base que per mantenir i defensar una disparitat conceptual és del tot indispensable tenir una argumentació sòlida, subjecta a canvis.

L'argumentació comprèn, doncs, un espectre ampli d'aptituds cognitives i lingüístiques, que cal organitzar. Per fer-ho ens remetem al model d'argumentació pro- 


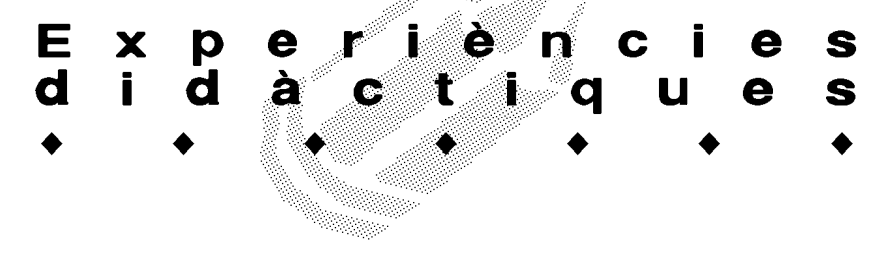

posat per Toulmin, Rieke i Janik (1979), postulats que creiem que són els que generen més consens de partida per a l'estudi teorico-pràctic de l'argumentació. Per als propòsits d'aquest article, es fa imprescindible repassar breument els components de l'argumentació que aquests autors estableixen. L'argumentació es contempla com una transacció crítica d'idees, i per això té un carácter interpersonal. Cal comptar, d'entrada, amb una afirmació determinada, una asserció que hom fa en relació amb un tema donat. Aquesta afirmació se sustenta en una sèrie de raons. Les raons són els fets particulars que una persona aporta per tal de fonamentar l'afirmació emesa. Les raons poden requerir una norma de caràcter més general que les relligui i que elevi el discurs a un grau més alt de generalitat, o li doni validesa universal. Parlarem aleshores d'un aval. D'altra banda, si el discurs argumentatiu requereix encara una gradació de fonamentació superior, haurem de recórrer a una llei o teoria que reuneixi el consens establert dins un àmbit de coneixement determinat. Cal indicar que aquests passos o seqüències no són del tot visibles en el discurs, però sí que ho són en el resultat final del procés argumentatiu.

El procés, pel que hem explicat, no és acabat. Sovint és també imprescindible preveure si l'afirmació és vàlida en tots els supòsits, i examinar les refutacions o situacions en les quals es donarien excepcions a allò afirmat. També és possible que emetem l'afirmació amb total certesa, amb un grau determinat de dubte, 0 des d'una opinió personal no gaire contrastada. Haurem, en aquest cas, d'emprar una modalitat que matisi el nivell de certesa amb què fem l'afirmació.

Presentada la qüestió, convé, segurament, tractar de clarificar aquests conceptes: caldrà recapitular els elements de l'argumentació proposats per Toulmin i fer-ho amb un exemple. Imaginem que un interlocutor ens adreça el següent paràgraf: "Segurament, l'Anna votarà a les properes eleccions. Ja fa una colla d'anys que és major d'edat, és una ciutadana com tu i com jo, que viu en aquest país! Tots els ciutadans del país tenen dret a vot, no? Si no és estrangera, segurament votarà. Al capdavall, la Constitució ens reconeix a tots aquest dret."

Ens trobem amb una afirmació clarament formulada (l'Anna votarà a les properes eleccions). Aquesta afirmació se suporta en una sèrie de raons (és major d'edat, és ciutadana com nosaltres). A més d'aquestes raons referides a fets concrets, específics, trobem també una llei de carácter general que la referma, un aval (tots els ciutadans del país tenen dret a vot). Aquest aval, al seu torn, es remet a una norma universal o teoria que n'és el garant últim (la Constitució reconeix el dret a vot). Hi ha, però, circumstàncies especials que posarien en qüestió l'afirmació, que es contemplen a la refutació (si no és estrangera). En qualsevol cas, tot el paràgraf no deixa de ser una suposició; l'emissor no té la certesa absoluta que l'afirmació s'acompleixi. Empra, doncs, una modalitat (segurament l'Anna votarà).

Aquest repàs sumari als components de l'argumentació posa de manifest la solidesa del conjunt en el model, segons Toulmin. Seguint l'autor, aquest ha previst tots els components possibles i necessaris per a un discurs argumentatiu complet i coherent. És important comprovar també com tots aquests components del discurs lliguen entre si. Toulmin fa visibles les relacions estructurals entre els components citats amb un esquema com el que es mostra a la figura 1.

Ens trobem, doncs, amb un model de discurs argumentatiu. Confrontar les argumentacions dels alumnes de formació inicial de Mestres amb el model de Toulmin serà revelador en diversos sentits. Sorgeixen preguntes com: quins són els elements de l'argumentació més comunament emprats? Els alumnes són capaços d'adduir raons per sustentar de forma efectiva les seves afirmacions? Contrasten les raons donades amb normes generals, preveuen excepcions? Construeixen argumentacions coherents i fonamentades? El que presentem en aquest article és una primera aproximació a un treball que es troba en un procés d'estudi de tots els components.

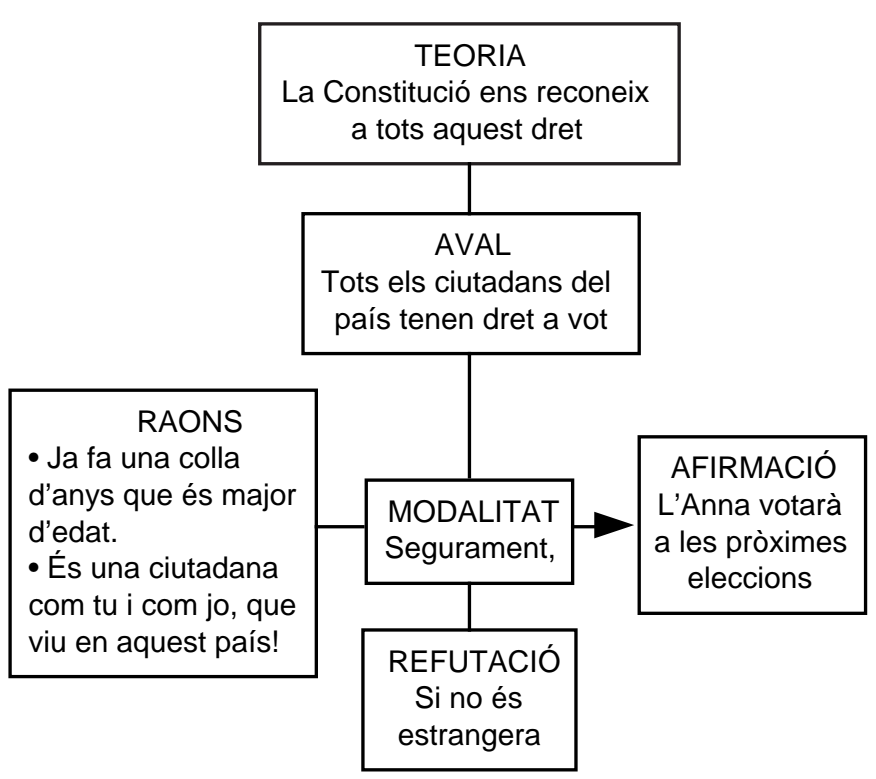

Figura 1. Relacions estructurals entre els components de l'argumentació 


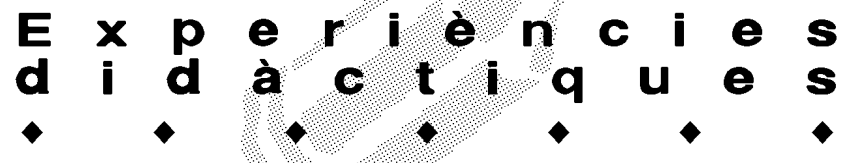

\section{L'argumentació en alumnes de Magisteri}

El primer pas va ser acotar l'objecte d'estudi i la definició d'un marc teòric. El model de Toulmin va ser adoptat després d'una primera revisió i debat sobre diverses aproximacions al tema de l'argumentació. Pel que fa a la recollida de dades, la metodologia de treball va ser la següent: vam establir cinc àrees d'argumentació relacionades directament, bé amb àmbits de coneixement (Ciències Socials, Educació Física, Art, Matemàtiques), bé amb àmbits d'interès educatiu de caràcter transversal (Ètica). A continuació va ser triada a l'atzar una mostra d'alumnes de les especialitats d'Educació Primària, Educació Física, Educació Musical i Llengua Estrangera de l'ensenyament de Mestres. Paral-lelament, vam elaborar un qüestionari per a cadascun dels àmbits esmentats, que tenia la funció de generar en els subjectes enquestats un discurs argumentatiu. Aquest discurs giraria, en cada cas, a l'entorn d'un tema directament relacionat amb l'àmbit específic.

Es tractava d'una situació basada en una pregunta a la qual el subjecte era confrontat, amb el requeriment de dir "què en pensava" i argumentar la resposta. Vegem-ne els enunciats:

Ciències Socials: "Es diu que el millor sistema polític o forma de govern com a organització social per resoldre els problemes de la ciutadania és la democràcia. Digues què en penses i argumenta la teva opinió."

Educació Física:"Es diu que la pràctica d'activitats físiques i esportives aporta sempre beneficis a les persones. Digues què en penses $\mathrm{i}$ argumenta la teva opinió".

Matemàtiques: "Dos alumnes discuteixen sobre si la diagonal d'un cub és més llarga que la diagonal d'una cara del mateix cub. Digues què en penses sobre aquesta qüestió matemàtica i argumenta el teu plantejament".

Art: (a partir d'una fotografia d'una obra artística contemporània): "Aquesta és una obra de Reinhard Mucha, un dels artistes alemanys més coneguts de la seva generació. Mucha treballa habitualment amb els materials i objectes que troba a l'espai d'exposicions, tot combinant-los i presentant-los de forma sorprenent. Digues què penses d'aquesta obra i argumenta la teva opinió".

Ética: "L'empresa que subministra la indumentària per a la neteja del 'chapapote' de la costa gallega pertany a la família d'un dirigent polític del govern. Argumenta, des del punt de vista moral, la teva posició sobre aquesta qüestió".

La validesa i les possibilitats d'aquests enunciats per a generar un discurs argumentatiu en els alumnes van ser debatudes pel grup en conjunt, tot i que la proposta inicial era feta pel representant de l'àrea específica. Els textos es passaren als subjectes en dues sessions diferenciades. La primera, amb tres supòsits per resoldre, i la segona, en els dos restants. La mostra es va passar a 31 alumnes, i cadascú va respondre els cinc casos lliurats.

Les respostes van ser analitzats per tal de destriar, dins el discurs, els elements de l'argumentació contemplats a l'esquema que hem presentat més amunt. Donat que l'adaptació d'un text continu a l'esquema de Toulmin podia prestar-se a més d'una interpretació, vam triangular les anàlisis efectuades per a cada àrea, confrontant-les amb el parer d'un altre company del grup de treball i amb el del grup en el seu conjunt. Així, la decisió de considerar que una frase determinada era l'afirmació central de l'argument, o bé una raó, o que un altre paràgraf constituïa, posem per cas, un aval, va ser producte d'un consens i no únicament d'una interpretació personal.

\section{Presentació dels resultats generals i una primera valoració}

Com ja s'ha apuntat, l'anàlisi global de totes les respostes està en una fase avançada d'estudi per part del grup. En aquest quadre només presentem una visió general dels elements de l'argumentació, ja enllestits, tabulats en funció de dos eixos o paràmetres. D'una banda, els elements subjectes a ser analitzats (afirmació, raons, modalitat, refutació, aval i suport), i de l'altre els resultats específics de l'àrea (Matemàtiques, Ciències Socials, Educació Física, Art, Ètica) i el total.

La seriació numèrica que adjuntem tot seguit inclou les respostes de cada alumne per a les cinc àrees objecte d'estudi, i la xifra sumativa total de les respostes dels 31 alumnes que participaren en la mostra, que per a les cinc àrees implica un màxim de 155 . Per a una correcta comprensió, cal assenyalar que l'element de l'afirmació implicà que a Matemàtiques, Educació Física, Art i Ėtica hi hagués 31 afirmacions per a cada àrea, mentre que a Ciències Socials n'hi hagué 30 , amb un total, per a aquest element, de 154. En el quadre (Figura 2) es presenten les respostes per a cada element $\mathrm{i}$ àrea. No es contempla que un alumne hagi formulat dues o més variants d'un element.

D'una primera anàlisi quantitativa dels elements que apareixen en les argumentacions podem formalitzar quatre categories, atenent les xifres totals: una, les afirmacions $i$ les raons obtenen freqüències totals altes, superiors a les 140 respostes, sumatives de les 


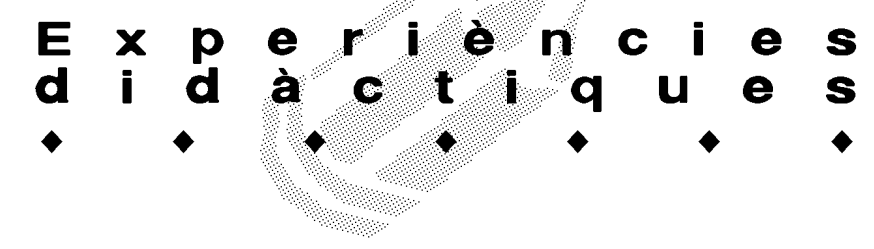

respostes de totes les àrees; una segona, la modalitat, en una xifra que es concreta en les 87 respostes sobre les 155 de possibles; una tercera, la refutació i l'aval, amb freqüències quasi idèntiques, que es concreten al voltant de les 70 ; i un quart estadi indicat com a suport, que obtindria una xifra de només 5 validacions.

Afirmacions i raons: El quadre, en una primera valoració, implica que els 31 alumnes de Magisteri que participaren en la mostra, davant dels enunciats proposats, aportaren, sobretot, afirmacions -154-, i raons -148-, sobre un màxim possible de 155, resultat molt per sobre d'altres elements. D'aquesta manera, la ratio d'afirmació i raó que aportà cada alumne al qüestionari respost pot catalogar-se com a alt.

Modalitat: El segon bloc de respostes és l'aportació quantitativa de modalitat, en una xifra global de tots els alumnes, que arriba a la suma de 87. La xifra és relativament baixa, ja que només supera lleugerament la meitat del total possible de respostes -155-, que hauria sortit en el cas que cada alumne n'hagués indicat una en cada pregunta de l'àrea que va respondre.

$\begin{array}{lrrrrrr}\text { Element/àrea } & \text { Mat. } & \text { CS } & \text { EF } & \text { Art } & \text { Etica } & \text { Total } \\ \text { Afirmació } & 31 & 30 & 31 & 31 & 31 & 154 \\ \text { Raons } & 28 & 30 & 30 & 29 & 31 & 148 \\ \text { Modalitat } & 10 & 22 & 16 & 18 & 21 & 87 \\ \text { Refutació } & - & 23 & 20 & 9 & 18 & 70 \\ \text { Aval } & 10 & 19 & 15 & 16 & 9 & 69 \\ \text { Suport } & 3 & 2 & - & - & - & 5\end{array}$

Figura 2. Nombre d'alumnes sobre 31 que han fet servir l'element indicat de l'argumentació per a cada àrea

Refutació i aval: El tercer pla de respostes, la refutació i l'aval, encara seria inferior al segon bloc -només 70 i 69 entrades, respectivament-, aspecte que ens demostra que més de la meitat de la mostra dels alumnes de Magisteri no empraren aquests elements en l'exercici argumentatiu.

Suport: En el quart pla, el suport, les respostes serien una caricatura del que fóra desitjable, ja que només 5 casos sobre 155 possibles assenyalen que ens trobem davant d'un element que els alumnes fan servir escassament en una argumentació.

Tanmateix, si l'anàlisi es realitza en funció de les respostes a cada una de les cinc àrees, detectem semblances i aspectes dissonants. Vegem-hi les que tenen un nivell general de semblances:

En les respostes a l'afirmació i a les raons, s'hi observa una semblança remarcable quant al nombre de respostes, en la banda entre les 28 i les 31 per a cada element. Aquesta similitud pot portar a pressuposar que segurament un bon nombre d'alumnes de Magisteri, davant d'un supòsit argumentatiu, utilitzen les afirmacions i raons, aspecte que ja anunciem que presenta una gran variabilitat quant a nombre, almenys en el que pertoca a les raons.

Un segon aspecte és l'escassa aportació a la variant del suport, ja que només en cinc casos s'utilitza. Tot i que la freqüència és reduïda -de 0 a 3 alumnes en fan esment en alguna àrea-, la dispersió és evident, amb àrees -Educació Física, Art i Ètica- on en l'exercici argumentatiu no hi ha ni un sol alumne que ho prengui en consideració.

Respecte a la dispersió de freqüència de respostes en funció de l'àrea, observem:

Les primera serien les escasses 10 aportacions en l'element de la modalitat de l'àrea de Matemàtiques, en comparació amb les altres àrees, que van des de la franja entre els 16 de la mínima i els 22 de la màxima. L'indicador que hi hauria de sortir en l'àrea de Matemàtiques, seria el dubte a una certesa, cosa que detectem que a l'àrea no es dóna amb tanta freqüència com a les altres, presumiblement pel fet de ser una ciència que en molts dels seus postulats és exacta.

Una segona peculiaritat que observem és la forta dispersió de respostes respecte a la refutació, en un grau molt acusat. Enfront de la la nul-la resposta a l'àrea de Matemàtiques, hi ha 23 casos detectats a l'àrea de Ciències Socials, com a xifra màxima, contraposats a l'exigua xifra de 9 refutacions a Art, que en tot cas representarien la meitat de les que presenten les altres dues àrees, Educació Física i Ètica. Considerant que la refutació posa en qüestió l'afirmació, veurem que aquesta es presenta en plantejaments de preguntes obertes al diàleg i a la confrontació, representat en el cas que ens ocupa, en les preguntes de Ciències Socials, Educació Física i Ètica.

Un darrer element de comentari seria la premissa de l'aval. Entesa com una llei general que referma les raons, en les respostes dels alumnes de Magisteri hem trobat que hi ha aportacions a totes les àrees en xifres no altes, que sobresurten en l'àrea de Ciències Socials -19-i que són més escasses en les àrees de Matemàtiques i d'Ètica.

\section{Apreciacions finals}

De l'anàlisi del precedent destacaríem unes apreciacions finals:

1. S'observa una tendència per part dels alumnes a identificar l'argumentació amb el simple fet de presentar una afirmació i donar algunes raons.

2. S'observa una influència a no plantejar possibles 


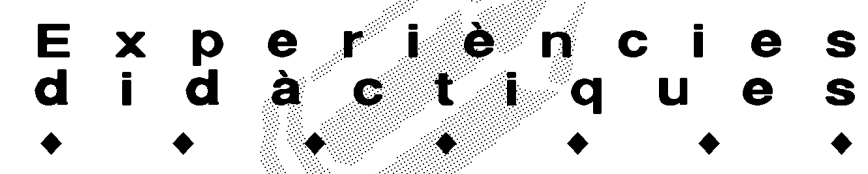

excepcions a l'afirmació presentada. Menys de la meitat de la mostra no aporta cap refutació a l'afirmació.

3. S'observa una propensió a no recolzar l'afirmació amb avals, enfeblint l'argumentació presentada.

4. S'observa una tendència fortíssima a no aportar cap suport a l'argumentació, la qual cosa podria relacionar-se amb una manca de domini conceptual de l'àrea en qüestió, o a no utilitzar-lo en les situacions en què ho reclama aquest coneixement.

Arribem a la conclusió que les argumentacions generades, formalment, són incompletes, ja que hi falten elements bàsics, segons el model de Toulmin. Tot això condueix a destacar que la formació reflexiva i crítica de l'alumnat de Magisteri ensopega amb una limitació de tipus procedimental, amb greus mancances respecte del procés de l'argumentació, i que l'assoli-

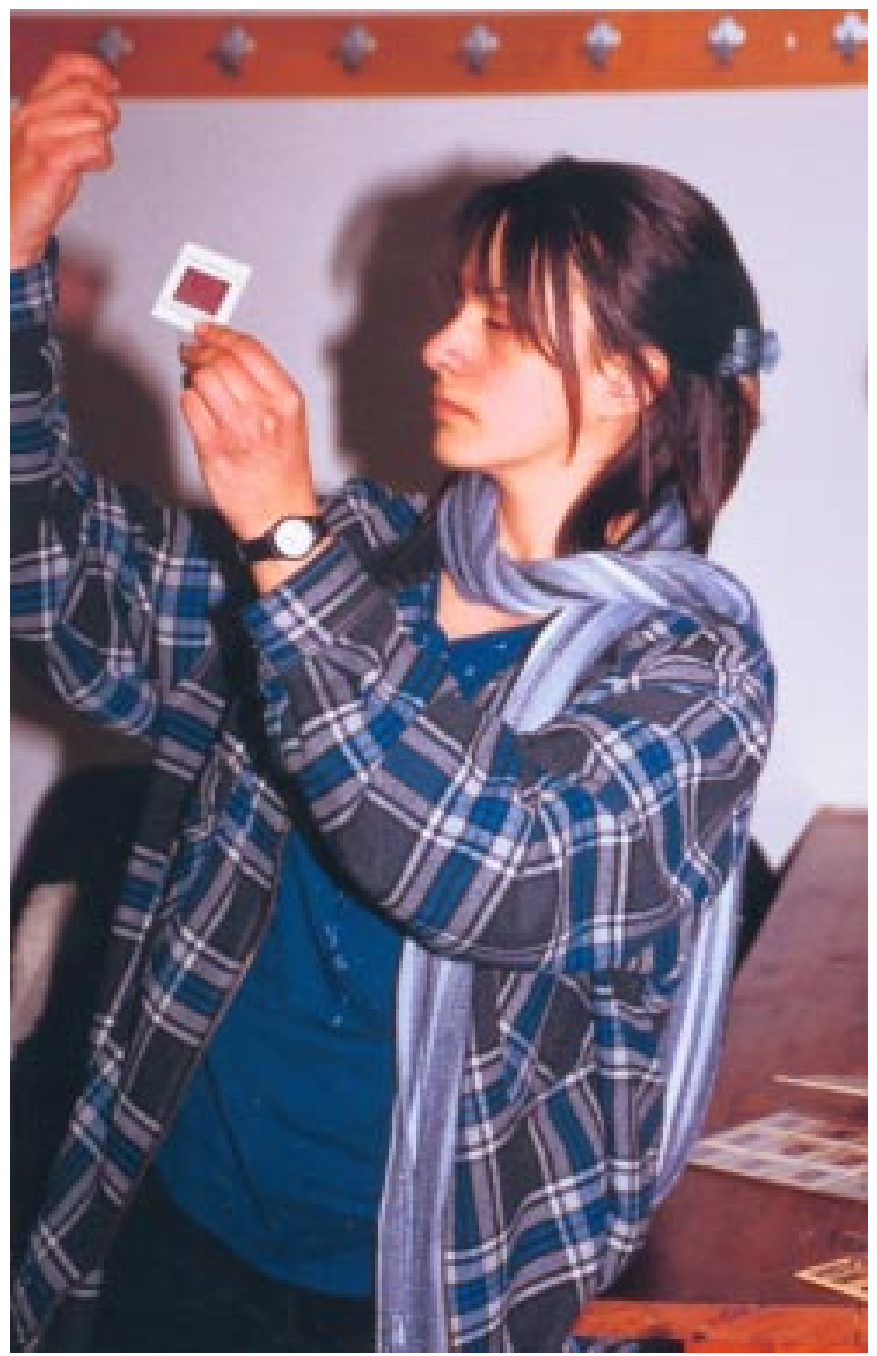

ment d'aquesta formació hauria de passar per un ensenyament i una pràctica pautada.

El conjunt del que presentem aquí -ja hem dit que és l'avançada d'un treball més ampli-permetrà analitzar els encerts i les mancances argumentatives dels alumnes de Magisteri en l'etapa de formació inicial. Creiem que aquest tema és una qüestió capital per prendre consciència, i sobretot solució individual, davant d'una pràctica professional encarada a fer pensar críticament sobre els continguts de les diverses disciplines a l'escola. La finalitat de la investigació haurà de ser la de validar els resultats i traslladar-los a la pràctica, buscant que els alumnes de Magisteri tinguin, en el futur, unes competències necessàries per a totes i cadascuna de les disciplines que han d'ensenyar a treballar. I que alhora sàpiguen transferir les seves capacitats i suficiència apreses des d'aquesta vessant als alumnes de l'ensenyament obligatori, futurs ciutadans.

\section{Referències bibliogràfiques}

AA.DD. (CAMPS, M.; CONDE, C.; GAVALDÀ, A.; GIRONDO, L.; MACAYA, A.; SALVAT, A; SANTISTEBAN, A.; VISCARRO, I.). Naturalesa de les creences, opinions ; judicis de l'alumnat de l'ensenyament de Mestres des del sobre les àrees curriculars, a CARMEN, L. Del (ed.). Simposi sobre la formació dels professionals de l'educació. Edita Institut de Ciències de l'Educació. Universitat de Girona. Girona. 2000.

CONDE, C. i GAVALDÀ, A.; SANTISTEBAN, A. Orígenes del pensamiento social en el alumnado de formación inicial, a PAGÈS, J.; ESTEPA, J.; TRAVÉ, G. (eds.). Modelos, contenidos y experiencias en la formación del profesorado de Ciencias Sociales. Edita Universidad de Huelva. Huelva. 2000a.

CONDE, C.; GAVALDÀ, A.; SANTISTEBAN, A. El pensament social dels estudiants de Mestre: llums i ombres. «Comunicació Educativa», 13 (2000b) 31-34.

GÓMEZ, I.; PRAT, A. Bases teòriques d'una proposta per afavorir la comunicació a l'aula, a JORBA, J. et al. Parlar i escriure per aprendre. Edita ICE de la Universitat Autònoma de Barcelona. Bellaterra. 1998.

MACAYA, A. i CONDE, C. Creencias, opiniones y juicios de los maestros en fase de formación inicial sobre arte y educación artística, a FOSATI, A., HUERTA, R.(eds.). Los valores del arte en la enseñanza. Reproexpres ediciones. Universitat de València. 2001.

TOULMIN, S.; RIEKE, R.; JANIK, A. An introduction to reasoning. Ed. McMillan. Nova York. 1997.

VISCARRO, I.; CONDE, C.; CAMPS, M. Creencias, opiniones y juicios del alumnado de Magisterio sobre el área de Didáctica de la Expresión Corporal, a CONTRERAS, O.R. (coord.). La formación inicial y permanente del profesor de Educación Física. Edita Universidad de Castilla-La Mancha. Cuenca. 2000. 